\title{
Fostering Active Readers: A Collaborative Map Creation Activity for Deep Comprehension
}

\author{
Mikiko Sudo \\ International Christian University, Tokyo, Japan \\ Asako Takaesu \\ International Christian University, Tokyo, Japan
}

\begin{abstract}
This paper describes the procedures of a multimodal activity combining different collaborative, communicative modes - the creation of group concept maps and oral presentation of the maps-to assist college-level students in deciphering complex academic texts. Based on the perspective of social constructivism (Vygotsky, 1978), the authors attempt to explore how the activity provided Japanese university students with an opportunity to confirm and validate their own understanding of the texts and modify and integrate their understanding with that of their classmates with the common goal of attaining a deeper level of comprehension.
\end{abstract}

Strong reading abilities are widely regarded as a crucial part of professional success. However, a considerable number of Japanese readers of English as a foreign language (EFL) are deficient in this area (Butler \& lino, 2005). While a variety of reasons account for the prevalence of this phenomenon, one could be attributed to a lack of practical solutions for fostering active reading (Robinson, 2011). Students in most university reading classes tend to passively consume the content of assigned texts without penetrating the underlying layers of meaning. Missing from many pedagogical practices are challenges that foist students into a more active role of reconstructing ideas through dialogue with texts, their authors, teachers, peers, and above all, the students themselves.

This paper primarily chronicles the authors' attempt to use concept maps as a means of empowering freshmen readers at a Japanese university to gain a deeper understanding of complex academic texts. Since its development in 1972 by Joseph D. Novak, concept mapping has been widely used in various educational environments as an effective method to facilitate the understanding of and relationships between essential concepts presented in texts. As Novak (1990), Novak and Cañas (2006), and others have pointed out, creating concept maps facilitates participants' learning processes by organizing and structuring new knowledge in relation to previously acquired knowledge. Concept maps work "as a kind of template or scaffold" (Novak \& Cañas, 2006, p. 7) to visually display networks of interrelated concepts and enable students to trace the evolution of their thoughts.

Language Education in Asia, 2012, 3(2), 184-195. http://dx.doi.org/10.5746/LEiA/12/V3/I2/A07/Sudo_Takaesu 
The paper begins with an overview of reading comprehension processes and the social constructivist approach based on the work of Vygotsky (1978). After a brief description of the set characteristics of a specific reading course at a Japanese university, the paper describes the procedures of the multimodal collaborative map creation activity and explores how it plays an essential role in facilitating students' reading comprehension at a deeper level.

\section{Reading Comprehension Processes}

Current reading models regard reading comprehension processes as multi-level. The quality of resulting memory, which has considerable impact on learning, varies significantly, depending on how deeply these processes are activated (Caccamise, Snyder, \& Kintsch, 2008). It is generally agreed that there are two major levels of comprehension: text-based and learners' mental model-based processes.

Text-based comprehension consists of local meaning operations and overall meaning operations. The former is primarily activated by decoding syntax or word meaning, whereas the latter is activated by establishing coherence in text meaning through activities such as writing summaries or defining key concepts. In either case, the level of comprehension generally results in memory consisting of only the surface features of texts or the gist of the text and the words or phrases actually used in it.

More challenges are a prerequisite to promote deeper comprehension processes. To this end, van Dijk and Kintsch (1983) argued that students must formulate their own mental representations of the contexts expressed by the authors, because people store knowledge in a powerful interlinked network by connecting what they read to what they already know. In other words, by creating a mental model, readers' newly comprehended information will be transformed to learned information by becoming a part of their own pre-existing knowledge network.

Activities necessary to enhance the above processes value what readers bring to the texts more than what they decode in them. Creating concept maps is therefore effective, since it requires readers' active interpretive and inferential analysis of the content, including abstractions or the author's emotions implied in the texts. The activity also demonstrates a variety of potentials for meaning-creation. By reading while focusing on what the key concepts are and how they are related, as well as expressing comprehension through a visual display, readers go through multiple tracks to build a stronger knowledge basis. Thus, they go beyond the limitations of monomodal texts and reach hypertext comprehension by constructing their own "multidimensional meaning representation" (Caccamise et al., 2008, p. 84).

\section{Collaborative Learning and Social Constructivism}

The theory of constructivism echoes the view of the current reading comprehension models above in that "knowledge is not passively received but actively built up by the cognizing subject" (Glasersfeld, 1989, p. 162). Drawing on this concept, social constructivism underscores the social nature of learning in reference to children's cultural development. In the initial stages, children learn through culturally meaningful dialogues with others, such as caregivers or peers. In other words, their initial learning appears on the social plane, as learners are actively involved in an interpsychological meaning construction as a social being (i.e., intermental dialogue) (Vygotsky, 1978). At a later stage of learning, intrapsychological meaning construction, or learners' active involvement in meaning transformation in their own mind, is required. They internalize the shared understanding formulated through collaborative intermental dialogues and reconstruct the message in their own mind (i.e., intramental dialogue) to achieve functional and structural transformation of their knowledge. In a 
classroom setting, students should have opportunities to appropriate the shared lesson by reflecting their own understanding gained from involvement in joint activities with peers, and to use their own initiative to internalize their knowledge toward this goal.

\section{Procedures in a Collaborative Map Creation Activity Participants and Context}

This study took place in a private liberal arts university in western Tokyo. Reflecting the understanding of the theory and approach described above, an activity was conducted in a 70minute Reading Content Analysis (RCA) course, one of the core courses of a 2-year contentbased, intensive English language program. Students meet twice a week, read authentic unabridged texts, and learn various reading strategies and skills. Overall, 51 students in three winter RCA classes (average TOEFL score of 463) participated in the collaborative map creation activity.

\section{Training Stage in Spring and Fall Semesters}

Prior to this activity, students learned how to create concept maps as one of the main reading strategies to tackle authentic academic texts in the spring term. As a preliminary step to map creation, students learned how to find key words in a short text, "What Every Yale Freshman Should Know," by Morgan (1961). On the first day, they received concept map guidelines (Appendix A) and assessment criteria (Appendix B) and watched the teachers draw sample concept maps based on the first paragraph of the text. As homework, they drew their own concept maps of the second paragraph and in the next class shared and discussed their work in small groups. Teachers selected some of the better concept maps and showed them to the whole class. The same procedure was repeated three or four times until the students had created maps covering the whole text. Before finalizing the maps, most teachers met with students privately for 15 minutes to clarify, confirm, and sort out any problems. Finally, their maps were collected and teachers evaluated them according to the assessment criteria.

This map creation activity was repeatedly conducted in this course. Teachers gave the students decreasing degrees of support from the spring to fall to winter terms, gradually leaving initiative to the students. For example, in the fall term, for the purpose of distinguishing facts from opinions as well as understanding the interrelationships between historical events, students drew concept maps for part of one chapter of The Evolution of Racism: Human Differences and the Use and Abuse of Science by Shipman (1994). Specific instruction was not given except for teachers showing sample maps created by students in previous years. The text was divided into four chunks, and students created four maps covering each chunk as homework. In class, they discussed the content of each segment while sharing their maps and clarifying difficult points. By the winter term, most students had acquired a certain degree of competence in map creation skills.

\section{Procedures of the Activity}

The reading material used for this activity was "Human Security Now - Protecting and Empowering the People" by Ogata \& Cels (2003). As preparation for the activity, students were instructed to read a sub-section, "Human Security's Distinctive Breadth" from the text (Appendix C). The reading was assigned as homework. In addition, students were asked to make their own concept maps. In class, students were divided into groups of four, and each group was given whiteboard markers and an erasable magnetic poster sheet to affix to a wall. Each group stood in front of their sheet and the group members shared their understanding of the assigned text, using their individually created maps. As they exchanged ideas, they produced a new group map synthesizing the ideas of each member. Because the sheets were 
erasable, students were able to hone their final concept maps as new ideas arose. This segment of the activity took 25 minutes.

After the group maps were finished, students had 10 minutes to individually plan an oral summary of their maps. Two students from each group remained in front of their group maps and explained the maps to visiting students and answered questions in a short poster presentation format. The other members from each group moved to the other groups' maps. Students switched roles until everyone had presented. The poster session lasted for 25 minutes.

Some of the better maps were later posted on the wall near the instructors' offices to inspire and motivate students in future map making (Figure 1). After the class, an online survey consisting of 10 questions was administered to ascertain students' perceptions of the activity (see Appendix D) and twenty-nine students responded. Comments made in English have been edited for fluency; the content is unchanged.
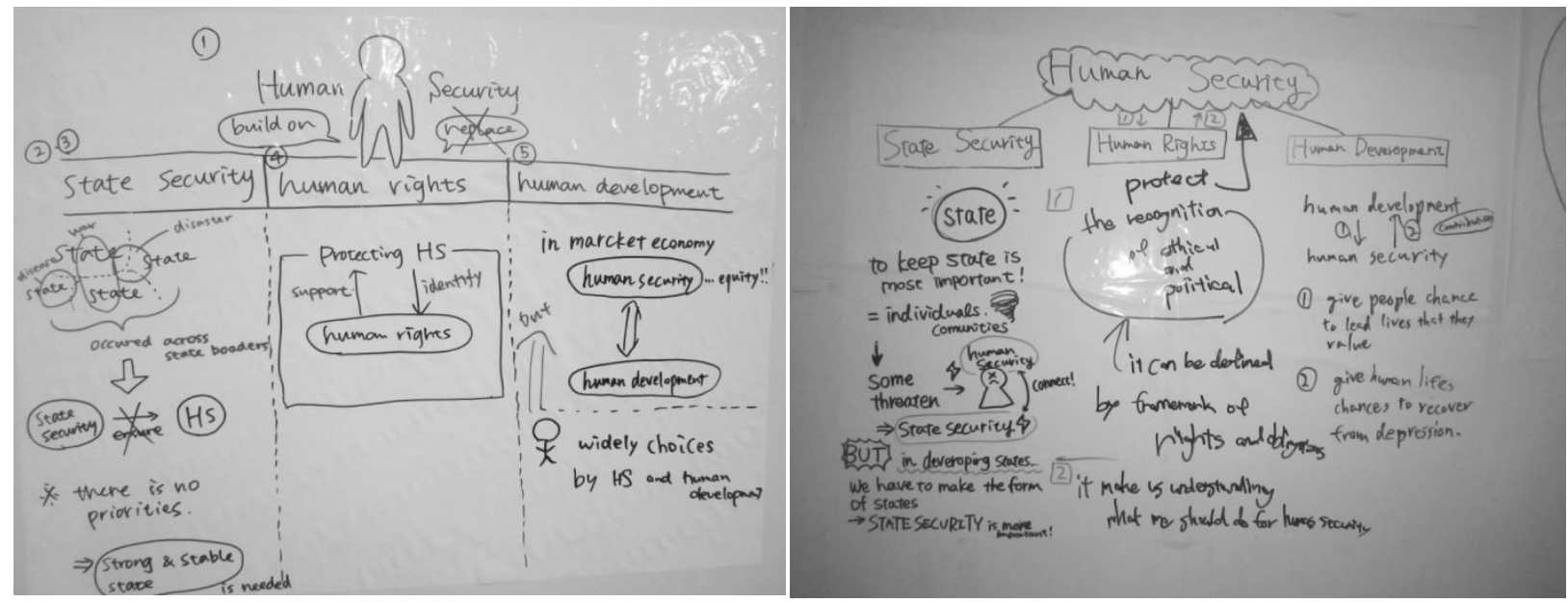

Figure 1. Pictures of student concept maps.

\section{Survey Feedback}

Of the 29 respondents, $27(93 \%)$ indicated that the activity helped them to understand the content of the text. More than half of the students found the activity challenging, as $55 \%$ of them responded that it was either very difficult (7\%) or difficult to some extent $(48 \%)$ to create a new map while discussing it with other students.

The majority of those students pointed out different interpretations of the texts held by each student as the main source of the difficulty. One student stated, "In some parts, we had different interpretations and it was difficult for us to sum up our ideas in one map." Another student noted, ". . . because how to interpret the texts differs from each other, our opinions collided." As for the new group map created with other students, 7 students (24\%) responded that it was very different and $10(34 \%)$ indicated that it was different to some extent from their original maps. Out of these 17 students, 14 (82\%) reported that their understanding of the parts that were different from their own maps deepened after the activity. One student mentioned, "[The group map] showed further improvement from my map and included important points I had not noticed by myself. Also, the final map became much clearer than mine." Another stated, "What I wrote myself had too much information in it, but the group map got clearer and more organized as we were able to select the most important information through our discussion." In other words, it appears that they benefited from the differences, became 
actively involved in discussion or intermental dialogue with peers, and strengthened their understanding while integrating their ideas with others.

Producing new maps as a group was difficult for many students, but at the same time, the activity provided them with an opportunity to confirm the validity of their own understanding of the text, and modify and integrate each other's ideas with a common goal. In particular, having students conduct this with the poster sheets allowed them to freely express their opinions and promoted lively and active discussion.

Regarding the poster session in which students explained their group maps to other students and asked questions about other groups' maps, $12(41 \%)$ responded that it was very useful and $15(52 \%)$ indicated it was useful in terms of deepening their understanding of the texts. Of the oral summary, one student commented, "In order to give a presentation, we had to explain what we had understood. It required us to clarify the structure of the whole section and the relationship of each paragraph." Another student noted, "I could more clearly see the flow of the author's messages and how they are related." Another commented, ". . . and in order to make an explanation for other students, I had to think more about the way we created our map and its content." One student mentioned that as audience members, "we were able to clarify the points that we had not been sure about. Also, [during the question-answer session], we were able to help students in other groups with the parts they seemed to be having a hard time understanding." Another student stated, "It was interesting to see the maps made by other groups because it allowed us to see different ways to interpret ideas and how differently other students expressed them." The results above are summarized in Table 1.

\section{Table 1}

\section{Survey Results}

\begin{tabular}{|c|c|c|c|}
\hline Questions & Responses & $n$ & Percent \\
\hline \multirow{2}{*}{$\begin{array}{l}\text { 1. Did this activity help you understand the } \\
\text { content of the text? }\end{array}$} & Yes & 27 & 93 \\
\hline & No & 2 & 7 \\
\hline \multirow{3}{*}{$\begin{array}{l}\text { 2. Was creating a new map while discussing it } \\
\text { with others was difficult? }\end{array}$} & Very difficult & 2 & 7 \\
\hline & Difficult to some extent & 14 & 48 \\
\hline & Not difficult & 13 & 45 \\
\hline \multirow{3}{*}{$\begin{array}{l}\text { 5. Was the group map different from your } \\
\text { individual map? }\end{array}$} & Very different & 7 & 24 \\
\hline & Different to some extent & 10 & 34 \\
\hline & Similar & 12 & 41 \\
\hline \multirow{2}{*}{$\begin{array}{l}\text { 7. Was your understanding on the different points } \\
\text { deepened? }\end{array}$} & Yes & 14 & 82 \\
\hline & No & 3 & 18 \\
\hline \multirow[t]{3}{*}{ 8. Was the poster session useful? } & Very useful & 12 & 41 \\
\hline & Useful & 15 & 52 \\
\hline & Not useful & 2 & 7 \\
\hline
\end{tabular}

Note. Q1, 2, 3, and 5: $n=29 ; \mathrm{Q} 7: n=17$

Presenting the finished products to other students appeared to have furnished both parties with a deeper understanding of the text. Even though the time allotted on the poster session was short-30 minutes including individual planning time-verbally explaining visualized concepts to others provided the students with opportunities to facilitate their intramental dialogue or reexamine and re-construct already received messages in their own minds as well as promoted 
intermental dialogue with the author, texts, and peers. Furthermore, the multimodal and recursive nature of this activity_drawing maps individually and collectively, discussion with group members and listening to other groups' presentations while looking at visual displays of their comprehension-appeared to have further promoted students' deeper understanding of the texts.

\section{Discussion and Conclusion}

The activity presented in this paper was introduced to a limited number of students. The number of respondents to the survey was small as well. Consequently, no precise generalization as to its effectiveness can be made. Nevertheless, students' overall responses to the activity were very encouraging. One of the major challenges in conducting this activity is when and how to give feedback to students. It is crucial for teachers to identify and correct students' misconceptions if they occur during the learning process. However, in this collaborative student-centered activity, it is probably better if teachers act as facilitators rather than directors when correcting errors. Excessive teacher guidance in the formulation stage of the group maps and oral presentations hinders students' willingness to actively participate. One method used in this activity was to show a teacher's map as a model at the end of the class to point out and correct some misunderstandings, rather than showing it at the beginning of the class. Additionally, teachers could do the following:

- show a teacher's map in the following class, if there are time constraints

- provide a whole-class question-answer session at the end

- ask students to write a summary of the part of the text covered by maps

- ask students to draw individual maps which reflect their new understanding gained through the activity

Another drawback was the limited amount of time designated for this activity. Due to the short class time of 70 minutes, together with the busy course schedule of the winter term, the total time spent on the whole activity was only 60 minutes. Therefore, students had to rush through discussions to complete their group maps and give the presentations on time. Obviously this hindered students from creating more elaborate group maps as well as from optimizing their learning experience. To promote deeper comprehension of complex texts, teachers could stretch this activity into several classes. Table 2 shows suggested lesson plans. 


\section{Table 2}

\section{Suggested Lesson Plans}

\begin{tabular}{|l|l|}
\hline Class & Lesson \\
\hline Class 1 & $\begin{array}{l}\text { As homework, assign a part of a text for individual map creation. Identify key words } \\
\text { with the whole class, if necessary. }\end{array}$ \\
\hline Class 2 & $\begin{array}{l}\text { Using the first half of the class, let students share their maps and discuss the content } \\
\text { of the text in small groups. For the rest of the class, students complete group maps. } \\
\text { As homework, students make notes based on their maps and prepare for a poster } \\
\text { session in the following class. }\end{array}$ \\
\hline Class 3 & $\begin{array}{l}\text { Students rehearse for the poster session with the same group members from the } \\
\text { previous class. The poster session continues for 30-40 minutes. At the end, hold a } \\
\text { question and answer session and discuss any problems encountered related to the } \\
\text { maps. }\end{array}$ \\
\hline Class 4 & Let students write summaries of the group maps without reading the text. \\
\hline
\end{tabular}

Note. For assessment, teachers could evaluate group maps from Class 2 and individual summaries from Class 4 . The assessment ratio could be $50 \%$ for the group map and $50 \%$ for the individual summary.

In this activity, each class consisted of approximately 20 students. If the class size is larger, teachers could ask each group to select a representative to give a short presentation of their group map in front of the class. As an alternative, teachers could set two days for the poster session.

Many students regarded this activity not only as meaningful, but also as enjoyable. For instance, one student noted, "we discussed a lot with each other with the goal of making the group map together, it deepened our communication, and it was fun." One of the most important values of this activity lies herein-the students' enjoyment and excitement in reaching deeper comprehension of texts through collaboration. Unlike traditional teachercentered reading classes, discovering and expressing meaning is imperative for students throughout the activity, and this imperative functions as a dynamic impetus to transform students from passive to active readers.

\section{Author Note}

Mikiko Sudo, International Christian University, Tokyo, Japan; Asako Takaesu, International Christian University, Tokyo, Japan.

Correspondence concerning this article should be addressed to Mikiko Sudo, International Christian University, 3-10-2 Osawa, Mitaka, Tokyo 181-8585, Japan, and Asako Takaesu, International Christian University, 3-10-2 Osawa, Mitaka, Tokyo 181-8585, Japan. E-mail: mikikosd@gmail.com; asatakaesu@gmail.com 


\section{References}

Butler, Y. G., \& lino, M. (2005). Current Japanese reform in English language education: The 2003 "Action Plan." Language Policy, 4(1), 25-45. http://dx.doi.org/10.1007/s10993004-6563-5

Caccamise, D., Snyder, L., \& Kintsch, E. (2008). Constructivist theory and the situation model: Relevance to future assessment of reading comprehension. In C. C. Block \& S. R. Parris (Eds.), Comprehension instruction (2nd ed., pp. 80-97). New York, NY: Guilford.

Glasersfeld, E. v. (1989). Constructivism in education. In T. Husen \& T. N. Postlethwaite (Eds.), The international encyclopedia of education: Research and studies (Supplementary Vol.1, pp. 162-163). Oxford, England: Pergamon Press.

McLeod, H. (2001). Sample rubric for a concept map. Retrieved from http://www.ohassta.org/resources/generalresources.htm

Morgan, E. S. (1961). What every Yale freshman should know. In D. Danielson \& R. Hayden (Eds.), Reading in English (pp. 27-33). Englewood Cliffs: Prentice Hall.

Novak, J. D. (1990). Concept maps and Vee diagrams: Two metacognitive tools to facilitate meaningful learning. Instructional Science, 19, 29-52. http://dx.doi.org/10.1007/BF00377984

Novak, J. D., \& Cañas, A. J. (2006). The theory underlying concept maps and how to construct them (Technical report IHMC CmapTools 2006-01). Pensacola: Florida Institute for Human and Machine Cognition. http://cmap.ihmc.us/Publications/ResearchPapers/TheoryUnderlyingConceptMaps.pdf

Ogata, S., \& Cels, J. (2003). Human security - Protecting and empowering the people. Global Governance, 9(3), 273-282. Available at http://www.jstor.org/stable/27800482

Robinson, K. (2011). Out of our minds: Learning to be creative (Rev. ed.). West Sussex, England: Capstone.

Shipman, P. (1994). The evolution of racism: Human differences and the use and abuse of science. New York, NY: Simon \& Schuster.

van Dijk, T. A., \& Kintsch, W. (1983). Strategies of discourse comprehension. New York, NY: Academic Press.

Vygotsky, L. S. (1978). Mind in society. Cambridge, MA: MIT Press. 


\section{Appendix A \\ Concept Map Guideline}

Creating a concept map of a text you've read is like

completing a jigsaw puzzle by putting pieces of information together.

Step 1: Prepare a large piece of paper without lines. From your memory, draw a concept map of what you understand about the text. Write down everything you can remember, following your train of thought.

- Use capitals to write major key words / ideas

- Leave a lot of space-you will fill it in later

- Show connections and relationships between key words / ideas

$>$ Focus related key words / ideas that radiate out from the center

$>$ Place related key words /ideas together

- Use several different types of lines and arrows and label them with linking words to show how they are related

- List to indicate the relative importance of each key word / idea

- Use circles to group related key words / ideas

- Add explanatory notes

Break: Look at your concept map and discover the gaps. Can you fill them in? Are there key words / ideas you don't quite understand? Are there connections you need to find out?

Step 2: Go back to the text and fill in the gaps. Find any missing key words / ideas or connections.

Step 3: Check the quality of your concept map. Randomly take a sentence from the text, and see if you can find a place for it. If you can, then it is a good concept map!

is Optional: Compare your concept map with your partner's. Discuss the content of the text and ask clarification questions. As you talk, fill in the gaps in your concept map with more information from your partner.

Break: Do you still have gaps? Are there some parts that do not make much sense? Are there key words / ideas you cannot fully explain? What more do you need to find out? 


\section{Appendix B \\ Assessment Criteria for Concept Maps}

(Adapted from McLeod, 2001)

\begin{tabular}{|l|l|l|l|}
\hline \multirow{2}{*}{ Criteria } & \multicolumn{3}{|c|}{ Performance Indicators } \\
\cline { 2 - 4 } & \multicolumn{1}{|c|}{$\begin{array}{c}\text { Level 1 } \\
\text { (1 point) }\end{array}$} & \multicolumn{1}{c|}{$\begin{array}{c}\text { Level 2 } \\
\text { (2 points) }\end{array}$} & \multicolumn{1}{c|}{$\begin{array}{c}\text { Level 3 } \\
\text { (3 points) }\end{array}$} \\
\hline \multirow{2}{*}{$\begin{array}{l}\text { Key words / } \\
\text { Ideas } \\
\text { (Concepts) }\end{array}$} & $\begin{array}{l}\text { Show minimum } \\
\text { number of key words / } \\
\text { ideas related to topic }\end{array}$ & $\begin{array}{l}\text { Show acceptable } \\
\text { number of key words / } \\
\text { ideas, and they } \\
\text { adequately relate to the } \\
\text { topic }\end{array}$ & $\begin{array}{l}\text { Show all significant key } \\
\text { words / ideas, and they } \\
\text { clearly relate to the } \\
\text { topic }\end{array}$ \\
\cline { 2 - 4 } & $\begin{array}{l}\text { Arrange key words / } \\
\text { ideas to demonstrate } \\
\text { basic understanding of } \\
\text { relationships between } \\
\text { them }\end{array}$ & $\begin{array}{l}\text { Arrange key words / } \\
\text { ideas to demonstrate } \\
\text { adequate } \\
\text { understanding of } \\
\text { relationship between } \\
\text { them }\end{array}$ & $\begin{array}{l}\text { Arrange key words / } \\
\text { ideas to demonstrate } \\
\text { insightful } \\
\text { understanding of } \\
\text { relationship between } \\
\text { them }\end{array}$ \\
\hline \multirow{2}{*}{$\begin{array}{l}\text { Linkages* } \\
\text { (Relationships) }\end{array}$} & $\begin{array}{l}\text { Indicate few } \\
\text { relationships by } \\
\text { connecting lines, } \\
\text { arrows, etc. }\end{array}$ & $\begin{array}{l}\text { Indicate many } \\
\text { relationships by } \\
\text { connecting lines, } \\
\text { arrows, etc. }\end{array}$ & $\begin{array}{l}\text { Indicate all } \\
\text { relationships by } \\
\text { connecting lines, } \\
\text { arrows, etc. }\end{array}$ \\
\hline $\begin{array}{l}\text { Eew added } \\
\text { Explanatory } \\
\text { notes** }\end{array}$ & $\begin{array}{l}\text { Added to show } \\
\text { adequate } \\
\text { understanding of the } \\
\text { contents }\end{array}$ & $\begin{array}{l}\text { Added to show } \\
\text { complete } \\
\text { understanding of the } \\
\text { contents }\end{array}$ \\
\hline
\end{tabular}

Total:

$/ 12$

Notes:

Linkages* mean to indicate relationships between key words / ideas by several different types of lines, arrows, etc.

Explanatory notes** mean your explanation about major key words / ideas 


\section{Appendix C \\ Human Security's Distinctive Breadth \\ from "Human Security - Protecting and Empowering the People" \\ (Ogata \& Cels, 2003)}

As a policy tool, the human security approach must demonstrate qualitative advantages in relation to other strategies. Human security does not replace but seeks to complement and build upon state security, human rights, and human development.

State security is essential but does not necessarily ensure the safety of individuals and communities. No longer can state security be limited to protecting borders, institutions, values, and people from external aggressive or adversarial designs. The spread of infectious diseases, massive forced population movements, human rights violations, famine, political oppression, and chronic conditions of deprivation threaten human security and, in turn, state security. Human security thus shifts attention from securing states and their institutions to protecting people within and across state borders. In doing so, it reinforces the assertion of sovereignty as a responsibility. ${ }^{9}$

Correspondingly, human security requires strong and stable states. Whereas the scope of state security is relatively focused, the breadth of human security is inherently broad and could lead to a dissipation of efforts if clear priorities are not established. Under certain conditions, state security can take precedence over human security interests. In such circumstances, all possible efforts should be made to protect people and minimize any adverse effects.

Respecting human rights is at the core of protecting human security. The 1993 Vienna Declaration of Human Rights stresses the universality and interdependence of all human rights. Human security provides a cognitive and practical framework for identifying the rights and obligations at stake in particular insecure situations. And human rights help answer the question, How should human security be ensured? The notion of legal duties and obligations complements the recognition of the ethical and political importance of human security.

Finally, in common with human security, human development is about widening the range of people's choices to lead lives that they value. But human security also accounts for unforeseen downfalls, or reversals of development. Given the volatility in financial and economic flows along with the spread of diseases and natural disasters, people may suddenly be faced with new insecurities and deprivations, reversing years of development. To the dictum of "growth with equity," human security adds the important dimension of "downturn with security," acknowledging the reality that downturns are common, especially in market economies, and are attributable to a combination of economic, social, environmental and political factors. ${ }^{10}$ 


\section{Appendix D \\ Survey Questions}

1. Do you think this activity helped you understand the content of Human Security? このアク ティビティーはヒューマンセキュリティーの内容を理解する上で役にたったと思います か?

2. Was it difficult to create a new map while discussing it with other students? 他の生徒と話 しながら新しいマップを作る事は難しかったですか?

3. If you chose "Yes" to Question 2, what made the map creation process difficult? Please describe your opinion below. 2 番の質問にYes と答えた場合、マップ制作が難しかった 理由は何だと思いますか?

4. If you chose "No" to Question 2, what made the map creation process smooth? Please explain your opinion below. 2 番の質問に No と答えた場合、マップ制作がスムーズに行 われた理由は何だと思いますか?

5. Was the collaborative map you created with other students different from your original map? 協力して作った新しいマップは自分で描いてきたマップと違うものになりました か?

6. If you chose "Yes" to Question 5, how was it different from your original map? 5 番の質問 にYes と答えた場合、どんな点が自分で描いてきたマップと異なりましたか?

7. If you replied to Question 6, do you think your understanding of the points you listed in Number 6 deepened? 6 番で挙げた点について、あなたの理解は深まったと思います か?

8. Was the poster session (in which you explained your group map to other students / and asked questions about other groups' posters) useful in terms of deepening your understanding of the text? ポスターセッションはテキストを理解する上で役に立ちまし たか?

9. If you chose "Yes" to Question 8, how was it useful? Will you describe particular aspects? 8 番の質問にYes と答えた場合、どんな点が特に役に立ちましたか?

10. Finally, how do you feel this collaborative map creation activity can be improved? How could it be better? 最後にこの協力してマップを制作するアクティビティーはどうしたら より良いものになると思いますか? 